and tested mainly in the laboratory; in 1929 , it was used on 3000 farms, and 30,000 metric tons of A.I.V. fodder was produced; in 1931, 100,000 tons was made on approximately 10,000 farms; and in 1932 the process is being used on 13,000 farms. All kinds of green crops have been ensiled, but legumes or young grass are best for feeding to milch cows.

The ordinary winter ration used in Finland for 800 -gallon cows consists of concentrates, turnips, hay and straw : in the A.I.V. ration, all the turnips and much (in some cases all) of the concentrates are eliminated, together with much of the hay. Expenditure on imported concentrates has been reduced by 50.80 per cent, and at the same time the milk yield has increased. The animals readily eat the fodder, ensiled grass being preferred. The free acid is said to disappear before the fodder is fed, but on most of the Finnish farms using the process a small amount of chalk is included in the silage ration. It has been found that the animals do not tire of A.I.V. fodder, and that their general health remains excellent: the distribution of lime and phosphorus in the teeth and bones, and of lime, phosphorus, and chlorine in the muscles and blood, remains normal. The quality of the milk resembles that of summer milk, both the butter-fat and protein contents being slightly higher than when the cows are fed on the ordinary winter ration; and the butter made from winter milk lacks its usual brittleness owing to the oleic acid-content being maintained at summer level. Further, the high vitamin content is held to be of great importance to public health, as the majority of the inhabitants of northern countries rely mainly on milk and milk products for their supplies of vitamins $A$ and $D$, and hitherto it has been found that the growth of children in Finland is practically confined to the months from July to December.
The only capital cost involved is that of making the silo pit, which has a diameter of $16 \frac{1}{2} \mathrm{ft}$. and a depth of $4 \mathrm{ft} .9 \mathrm{in}$. In Finland, where family labour is abundant and wood is cheap, this cost is very low. Unless the subsoil is chalk, the pit must be lined with wood, or with cement if there is danger of water seepage. A light wooden superstructure, which is transferable from pit to pit, must also be provided; it is placed over the pit when the green material reaches the ground level, and filling then proceeds until the superstructure is also full. The fresh material is then weighted, in a day or two it sinks to the ground level, and the superstructure is removed. Working costs vary with the crop ensiled, the yield per acre of the crop, and with the cost and efficiency of the labour. With labour, as in England, at about $8 d$. per hour, the cost per ton of dry matter (about twenty per cent of the green weight) is estimated to be about 22s. $6 d$. ; if to this figure we add $£ 2$ per ton of dry matter as the inclusive cost of growing grass for ensilage with the aid of manures, we obtain a total of $£ 32 s .6 d$. per ton, to which must be added a further small sum for cost of acid and depreciation of the silage pit.

Large-scale trials of the process are being made in Denmark as well as in Great Britain; in addition, the process has found a footing in Sweden and Norway; whilst in Germany, where some of Prof. Virtanen's claims are contested, the process, in its essential principles, has been officially adopted and is being widely advocated. If found to be a success in Great Britain, the adoption of the process will not only save the country millions of pounds per annum on imported concentrates, but will also provide what appears to be the only practical, economic solution of the problem of utilising flush growth of grass, which is one of outstanding importance in the management of grassland.

\title{
Buffalo-Fly in Northern Australia
}

HOR years past, serious complaints have come from cattle raisers in the northern areas of Australia about heavy economic losses due to irritation of stock by the buffalo-fly. This led the Commonwealth Council for Scientific and Industrial Research in 1930 to invite Prof. Eduard Handschin, of Basle, to undertake inquiries in Java and neighbouring islands, as well as on the mainland. The object was to examine possibilities of parasitic control of the pest. Prof. Handschin's full report is not yet available, but it is of interest at this stage to record some of the results of his eighteen months' work.

As with other alleged economic pests in Australia (flying fox, for example), careful inquiry has shown that Lyperosia exigua de Meijere, though serious in some places, is by no means responsible for all the damage hitherto attributed to it. This fly is present everywhere in the Dutch East Indies, where it is not regarded as a pest : its bad name in Australia is due in part to faulty observation. March and bush flies (Tabanus and Biomyia spp.) worry cattle more, in Handschin's opinion, than does Lyperosia. Loss of condition in travelling mobs is often put down to ' $f$ y worry' when it is due rather to innutritious dry grass and water scarcity. Further, the quality of the stock in northern Australia is admittedly low. This undoubtedly increases the attractiveness, or susceptibility, of the cattle to the fly. Poor quality of stock is probably a cause rather than an effect of the abnormally heavy infestation that is frequently observed. In short, it is usual to attribute all fly damage to Lyperosia and to make it the scapegoat for every economic loss in northern Australia.
Nevertheless, it remains a distinct menace to cattleraising, and its passage eastwards into the dairying herds of the coastal areas of Queensland might have serious results. Such spread is already occurring, but its geographic limits are set by conditions of temperature and humidity. The influence of these on time of development has been partially worked out by Handschin, who feels justified in maintaining that the buffalo-fly will never become established in the more southerly parts of Australia (western or eastern) and probably never farther south than Rockhampton in Queensland. There may be temporary incursions to lower latitudes, but they will not survive.

In the sparsely settled areas of the north, parasitism. seems the only possible means of control. Nieschulz had already found a number of parasites in Java, mostly primary parasites of saprophagous Muscida, not confined to any species of these, but as easily bred on Lyperosia as on them. Twelve of them were reared in the laboratories of the Veterinary Research Institute at Buitenzorg, and Spalangia sundaica Graham (n. sp.), which was the must abundant in the field, offered the greatest promise as a possible control for Lyperosia. The female lives about 27 days and lays $160-170$ eggs, each in a separate puparium of a fly.

There is a northem Australian species tentatively named $S$. orientalis Graham (n. sp.), morphologically quite distinct from $S$. sundaica, the female of which lives for 15 days and lays 75-85 eggs. In the hope of producing a more effective race, Handschin endeavoured to cross these two species. Males only were produced, indicating that fertilisation had not occurred. In the meantime, however, a special strain 
of $S$. sundaica was reared for several generations on Lyperosia puparia only, and when the male of this was crossed with $S$. orientalis female, remarkable results were obtained, the female offspring living 32 days (instead of 15) and producing 250 eggs (instead of about 80). In other words, the time of life of the indigenous species was doubled and the fecundity trebled, both highly important characteristics in a fight against Lyperosia. The roverse cross gave females living only 10 days, instead of the 27 of the $S$. sundaica female, and producing 100 eggs instead of 180 .

Five generations of the more promising cross were bred by Handschin, using all possible combinations of the parent and dorived stock. The results are certainly striking, but further research is urgently necessary. Arrangements are in train for breeding the first cross and releasing it in selected areas near Darwin. If results justify it, the work will be extended in the wet season to the Gulf Country in North Queensland. The chances of appreciable success are, how. ever, not great; hence no relaxation of quarantine restrictions can bo permitted. An interim report on Handschin's observations, including descriptions of $S$. sundaica and $S$. orientalis, has been published.

$$
\text { A. C. D. R. }
$$

\section{Liquid Fuels}

$\mathrm{T}$ HF second jubilee memorial lecture to the Society of Chemical Industry, given by Dr. A. E. Dunstan, deals with the whole question of the utilisation of petroleum, oil from coal, synthetic oils, and related subjects, and is printed in Chemistry and Industry for October 7 and 14. Natural gas is also dealt with.

Dr. Dunstan pointed out in what directions the industrial processes are undergoing modification. In the case of motor spirit, the tendency to gum formation, which is always present to some extent, is minimised by the addition of inhibitors such as di- and tri-hydric phenols and some aromatic amines and derivatives. Tendency to freezing in the case of spirit for use in military aviation is overcome by blending with methyl and ethyl alcohols, the hygroscopic properties of which may be restrained to some extent by the addition of benzene, amyl and butyl alcohols and phenol as binders.

A limit appears to have been reached in the increase of compression ratio possible without detonation even when special fuels are used, and research into the effects of other factors in engine design is suggested. The relation between chomical composition (paraffinic, naphthene, aromatic) and tendency to detonation in a fuel is not absolute, and anti-knock valuation can be made only by engine tests. The restriction on the use of cracked spirit for uviation may be removed if the authorities can be satisfied as to its keeping properties. Compression ignition (Diesel type) is steadily advancing in importance as compared with spark ignition, particularly for heavy transport, and Dr. Dunstan pointed out its advantages. Even if the price of fuel wero equal to that of petrol, there would still be a very substantial margin of benefit from compression ignition. The bearing of this on the liquid fuel industry was mado clear.

Tho production of oil from coal was carefully discussed and the conclusion reached that it appears to represent strategic rather than economic advantages. If the total coal used for power, heating, etc., as well as hydrogenation is taken into account, the most successful processes of hydrogonation will at present make only 1 ton of oil from 4 tons of coal, and the plant is not only extremely complicated but also exceedingly costly. Although hydrogenation appears to be the most hopeful line technically for the production of liquid fuels, its application to coal or even tar cannot be put forward at the present stage as a business proposition.

\section{University and Educational Intelligence}

Birmingram.-The Huxley lecture is to be delivered by Sir Arthur Salter in the Medical Theatre of the University, Hdmund Street, on December 1 at 5.30. The subject of the lecture is: "Next Steps in World Recovery".

Cambridge.-Sir Charles Sherrington, Waynflete professor of physiology in the University of Oxford, has been appointed Rede lecturer for the year 1933 .

W. G. Walter, of King's College, has been elected to the Michael Foster research studentship in physiology.

Dr. E. T. S. Walton, of Trinity College, has been awarded the Clerk Maxwell scholarship.

The Adam Smith prize has been divided between K. S. Isles, of Gonville and Caius College, and J. H. Kirk, of King's College.

Dr. N. J. T. M. Neodham, of Gonville and Caius College, has been approved for tho Sc.D. degree.

Tho Governing Body of Emmanuel College invites npplications for a research studentship which will be awarded in July 1933. The award will be made on evidence submitted by the candidates which should include (1) a birth certificate, (2) two certificates of good character, (3) a statement of the proposed courso of research, (4) evidence of general ability and of special fitness for the proposed course of research, supported by letters from two professors and other teachers, (5) a statement of emoluments or awards, already granted, or likely to be granted, from other bodies or persons and tenable at Cambridgo. Applications must be sent to the Master in time to reach him not later than June 30. Preferenco will be given to candidates who have already completed one but not more than two years of research. The studentship has a maximum annual value of $£ 150$ and is awarded and normally held for two years but may be renewed for a third year. The studentship is not tenable by a woman or by a graduate of the University of Cambridge.

London.-The University Court has gratofully accepted an offer received from $\mathrm{Mr}$. William Page to give to the University, subject to certain conditions, the copyright and material of the Victoria County History.

Tre building extension of the Northampton Polytechnic Institute, St. John Street, F.C.1, will be officially opened by H.R.H. Prince George on December 2, at 7 P.M.

THE twentieth election to Beit fellowships for scientific research will take place on or about July 14, 1933. Not more than three fellowships will be awarded on this occasion. Candidates must be graduates of a university of the British Empire and under twenty-five years of age. The annual value of a fellowship is $£ 250$ and it is tenable at the Imperial College of Science and Technology. Further information can be obtained from the Rector, Imperial College, South Kensington, London, s.W.7. 